\title{
Soil Amendments as GHGs Curtailers in Rice Fields
}

\author{
N. Kowshika ${ }^{\text {** }}$, N. Maragatham ${ }^{1}$, V. Geethalakshmi ${ }^{2}$, \\ M. Maheswari ${ }^{3}$ and S. Panneerselvam ${ }^{4}$ \\ ${ }^{1}$ Department of Agrometeorology, ICAR-KVK Vamban, Pudukkottai, India \\ ${ }^{2}$ Department of Agronomy, Agro Climate Research Centre, TNAU, Coimbatore, India \\ ${ }^{3}$ Department of Crop Management, TNAU, Coimbatore, India \\ ${ }^{4}$ Department of Environmental Science, TNAU, Coimbatore, India \\ ${ }^{5}$ Department of Water Technology Centre, TNAU, Coimbatore, India \\ *Corresponding author
}

\section{A B S T R A C T}

\section{Keywords}

Climate change,

Greenhouse gases,

Emission reduction

Article Info

Accepted:

04 November 2019

Available Online:

10 December 2019
Rice cultivation is being focused as a prime contributor to climate change due to the release of greenhouse gases into the atmosphere. In aspect to study the reduction of the GHGs emission, experiment trial was conducted with eight different soil amendment combinations viz., recommended dose of Fertilizers (RDF), fly ash, Biochar, Gypsum, Silica Solubilizing Bacteria (SSB), fly ash + SSB, Biochar + SSB, Gypsum + SSB. Gas collection was done at different crop growth stages using open bottom chambers and analyzed with Shimadzu GC-2014 gas chromatograph. Methane emission was observed less in applications of Fly ash (40.5 kg/ha), Fly ash + SSB (43.7 kg/ha) and Gypsum + SSB (45.5 kg/ha). Low levels of nitrous oxide emission were seen in applications of Fly ash + SSB (2.1 kg/ha), Gypsum + SSB $(2.2 \mathrm{~kg} / \mathrm{ha})$ and Fly ash $(2.2 \mathrm{~kg} / \mathrm{ha})$. Higher nitrous oxide and methane emission was found with the treatments of RDF, SSB, Biochar, Gypsum and Biochar + SSB. From the study, it was concluded that application of fly ash + SSB and fly ash did reduce the GHGs emissions on higher percentage over the application of other soil amendments in rice field.

\section{Introduction}

Rice being an important food crop of Asia contributes 35 to 60 per cent of the calories of 2.7 billion Asians (Pingali et al., 1997Delta areas, river valleys, and low lying coastal areas are the major rice producing areas in India. Food and Agriculture Organization (FAO) set its 2015 production forecast as 158.2 million tonnes (FAO, 2016). Settling to the influence of the El Niño phenomenon, during 2016 season, FAO anticipated 
production in India improve to 158.4 million tonnes, up 2 per cent from 2015 expectations. Tamil Nadu ranks fifth position in rice production in India with an area of 21 lakhs ha, with a production of 92 lakh M.T. (Metric Tonnes) and a productivity of $4381 \mathrm{~kg} / \mathrm{ha}$ (Department of Agriculture, 2014). In the current scenario, rice production is reported to be a contributor to climate change, through the release of greenhouse gases to the atmosphere.

There is a need for action on climate change, but global warming has not been reduced to safe levels. Scientists are overseeing a warming, exceeding $2^{\circ} \mathrm{C}$ by 2100 (IPCC, 2014), which would have far reaching consequences on food security, fresh water availability and the frequency and intensity of storms.

Nitrous oxide is one among the prominent greenhouse gases, being 298 times potential enough as $\mathrm{CO}_{2}$. Compared to other sectors, agriculture contributes heavily towards40$60 \%$ emissions of methane and nitrous oxide. Soils with nitrogen fertilizers are prone to release nitrous oxide.

While agriculture releases significant amount $\mathrm{N}_{2} \mathrm{O}$ to the atmosphere, it can efficiently be decreased by improving crop management (Smith et al., 2007). Methane $\left(\mathrm{CH}_{4}\right)$ stands second in the place of major greenhouse gas, with a global warming potential (GWP) 25 times that of carbon dioxide $\left(\mathrm{CO}_{2}\right)$. Methane is estimated to be responsible for 25 per cent of the anticipated warming (Forster et al., 2007). It is biogenically sourced from the anaerobic decay of organic matter.

Increased food demand may force the rising levels of methane gas to 50 per cent higher levels by 2020(Bouman, 1991). Nevertheless, Carbon dioxide is the major greenhouse gas to be understood at a larger cause. Subrahmanyam Desiraju et al., (2008) formulated a general rule that for every 75 ppm increase in $\mathrm{CO}_{2}$ concentration, rice yield found to be increased by 0.5 ton per hectare, but yield would get decreased by 0.6 ton per hectare for every $1{ }^{\circ} \mathrm{C}$ increase in temperature. Gerald et al., (2009) reported that based on impact of climate change on agriculture by 2050 , the rice price would increase between 32 and 37 per cent. They also showed that yield losses in rice could be between 10 and 15 per cent.

The problem starts where the major food production is indicated as the major source of a greenhouse gas and needs attention towards emission reductions. A headway towards reducing the GHGs emissions can be done with application of soil amendments to the rice crop field.

\section{Materials and Methods}

\section{Field experiment}

A field experiment was conducted in Tamil Nadu Agricultural University, Coimbatore, Tamil Nadu during Rabi (2015-16) season. The short duration rice variety $\mathrm{CO}(\mathrm{R}) 51$ was used in RBD with three replications and eight treatments viz., recommended dose of fertilizers alone (RDF), fly ash, biochar, gypsum, silica solubilizing bacteria (SSB), flyash + SSB, biochar + SSB, gypsum + SSB . Recommended dose of fertilizers (RDF) of NPK at 150: $50: 50 \mathrm{~kg} / \mathrm{ha}$, flyash at $20 \mathrm{t} / \mathrm{ha}$, biochar at $10 \mathrm{t} / \mathrm{ha}$, gypsum at $500 \mathrm{~kg} / \mathrm{ha}$ and silica solubilizing bacteria $(\mathrm{SSB})$ at $12.5 \mathrm{~kg} / \mathrm{ha}$ were the dosages applied. RDF was a default component in all the treatment combinations.

\section{Application of soil amendments}

Soil amendments and silica solubilizing bacteria were applied a day prior to transplanting into the plots with respective doses as given in treatment details. 


\section{Collection of air samples}

Gas samples were collected from the field using static closed chamber technique (Jain et al., 1999). As described by Khosa et al., (2010) each chamber was placed on the soil surface with $4-5 \mathrm{~cm}$ inserted into the soil, 10 minutes prior to each sampling for equilibration to reduce the disturbance so as to minimize the disturbance to the sampling site. Care was taken not to disturb the vegetation during the whole measurement program. After covering the plants with the chamber, four air samples were collected in Tedlar bags starting with zero time and subsequent sampling at an interval of 15 minutes using syringe and one way valve pump. As described by Jayadeva $e t$ al., (2009), the air samples were collected in the morning (09:00-10:00 hours) and in the evening (14:00-15:00 hours) and the average of morning and evening fluxes were used as the flux value for the day.

\section{Estimation of GHGs}

The gas samples were analyzed in a Shimadzu GC-2014 gas chromatograph equipped with FID.

\section{Results and Discussion}

The effect of soil amendments on GHGs emission from rice field is indicated in Table 1. In case of methane emission, higher emission was noted in RDF (54.9 kg/ha), and SSB $(53.2 \mathrm{~kg} / \mathrm{ha})$. Lower methane values were seen in applications of Fly ash $(40.5 \mathrm{~kg} / \mathrm{ha})$, Fly ash + SSB (43.7 kg/ha) and Gypsum + SSB $(45.5 \mathrm{~kg} / \mathrm{ha})$. Applications of Biochar + SSB (46 kg/ha), Biochar (46.9 kg/ha) and Gypsum $(47.5 \mathrm{~kg} / \mathrm{ha})$ also contributed to less methane. Emission reduction percentage from Table 1 states that Fly ash (26.2\%), Fly ash + SSB (20.5 \%) and Gypsum + SSB (17.2\%) are efficient in reducing methane emissions.
Although lesser to the above amendments, biochar + SSB (16.3\%), Gypsum (13.4\%) and biochar $(14.6 \%)$ did have reduced methane emission rates than RDF and SSB (3 $\%$ ) applications (Figure 1).

During the crop growth, significantly higher nitrous oxide emission was (Table 1) noted in RDF (2.7 kg/ha) and SSB (2.5 kg/ha). Lower nitrous oxide values were seen in applications of Fly ash + SSB (2.1 kg/ha), Gypsum + SSB $(2.2 \mathrm{~kg} / \mathrm{ha})$ and Fly ash (2.2 kg/ha). Applications of Biochar (2.4 kg/ha), Biochar + SSB $(2.3 \mathrm{~kg} / \mathrm{ha})$ and Gypsum $(2.4 \mathrm{~kg} / \mathrm{ha})$ contributed to less nitrous oxide emissions than SSB. Emission reduction percentage from Table 1 states that Fly ash + SSB (20.4\%), Gypsum + SSB (18.3 \%) and Fly ash (17.7\%) are efficient in reducing nitrous oxide emissions. Although lesser to the above amendments, biochar + SSB (16.2\%), Gypsum (14\%) and biochar (11.2 \%)did have reduced nitrous oxide emission rates than RDF and SSB (8.8 \%) applications (Figure 2).

Carbon di oxide has a different way of results (Table 1, Figure 3) compared to the nitrous oxide and methane emissions. Higher amounts of carbon dioxide release was found in Fly ash + SSB (56.8 t/ha), Gypsum + SSB (54.9 t/ha), Biochar + SSB (t/ha) and Gypsum (51.6 t/ha) applications. Whereas RDF (41.3 t/ha) and SSB (45.6 t/ha) had the lower rates of carbon dioxide emission. Fly ash (48.8 t/ha) and Biochar (46.8 t/ha) have contributed to more carbon dioxide than RDF and SSB.

Methane oxidation into carbon di oxide could be the reason for reduced methane emissions (Cicerone et al., 1981; Oremland1988). Gypsum reduces $\mathrm{CO}_{2}-\mathrm{C}$ equivalent emissions as in words of (Denier et al., 2002; Ali et al., (2007). Biochar acts as a slow C release source (Wardle et al., 2008) can minimize the methane emissions. 
Table.1 Greenhouse gases emissions under different soil amendments

\begin{tabular}{|c|c|c|c|c|c|c|}
\hline Treatment & $\begin{array}{c}\text { Methane } \\
\text { emission } \\
\text { (kg/ha) }\end{array}$ & $\begin{array}{c}\text { Methane } \\
\text { Percentage } \\
\text { Reduction } \\
(\mathbf{\%})\end{array}$ & $\begin{array}{c}\text { Nitrous } \\
\text { oxide } \\
\text { emission } \\
\text { (kg/ha) }\end{array}$ & $\begin{array}{c}\text { Nitrous } \\
\text { oxide } \\
\text { Percentage } \\
\text { reduction } \\
\mathbf{( \% )}\end{array}$ & $\begin{array}{c}\text { Carbon } \\
\text { di oxide } \\
\text { emission } \\
\text { (t/ha) }\end{array}$ & $\begin{array}{c}\text { Carbon di } \\
\text { oxide } \\
\text { Percentage } \\
\text { increase } \\
(\%)\end{array}$ \\
\hline RDF alone & 54.9 & & 2.7 & & 41.3 & \\
\hline Flyash & 40.5 & 26.2 & 2.2 & 17.7 & 48.8 & 18.3 \\
\hline Biochar & 46.9 & 14.6 & 2.4 & 11.2 & 46.8 & 13.4 \\
\hline Gypsum & 47.5 & 13.4 & 2.3 & 14.0 & 51.6 & 25.1 \\
\hline SSB & 53.2 & 3.0 & 2.5 & 8.8 & 45.6 & 10.4 \\
\hline Flyash + SSB & 43.7 & 20.5 & 2.1 & 20.4 & 56.8 & 37.5 \\
\hline Biochar + SSB & 46.0 & 16.3 & 2.3 & 16.2 & 52.2 & 26.4 \\
\hline Gypsum + SSB & 45.5 & 17.2 & 2.2 & 18.3 & 54.9 & 33.1 \\
\hline
\end{tabular}

*RDF was applied in all the treatment combinations

Fig.1 Methane emission

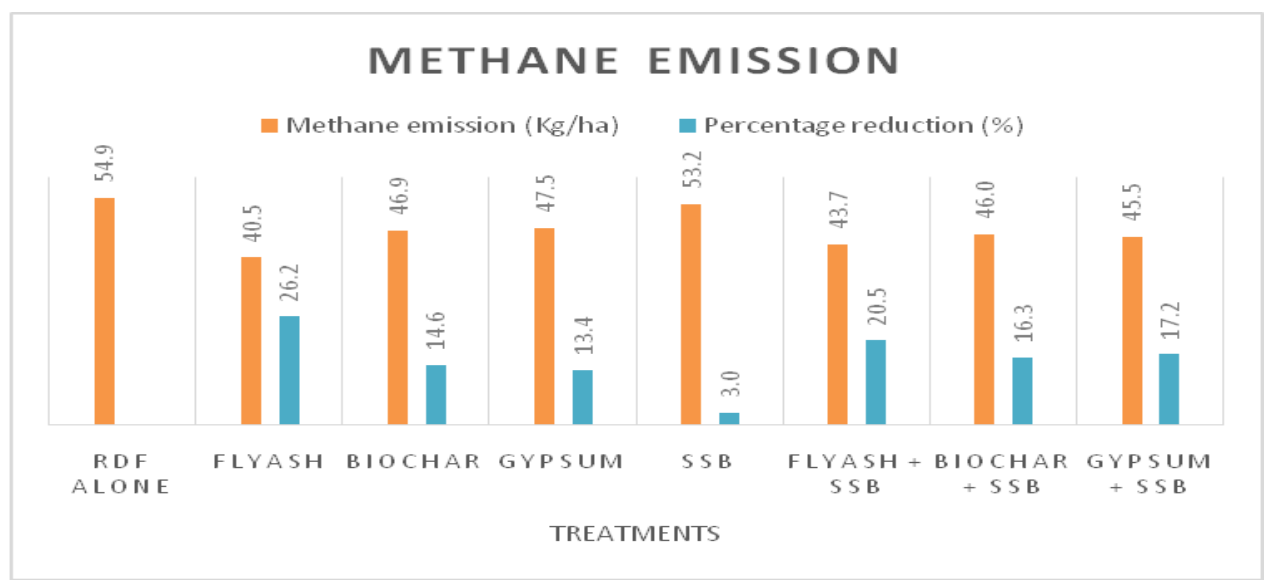

Fig.2 Nitrous oxide emission

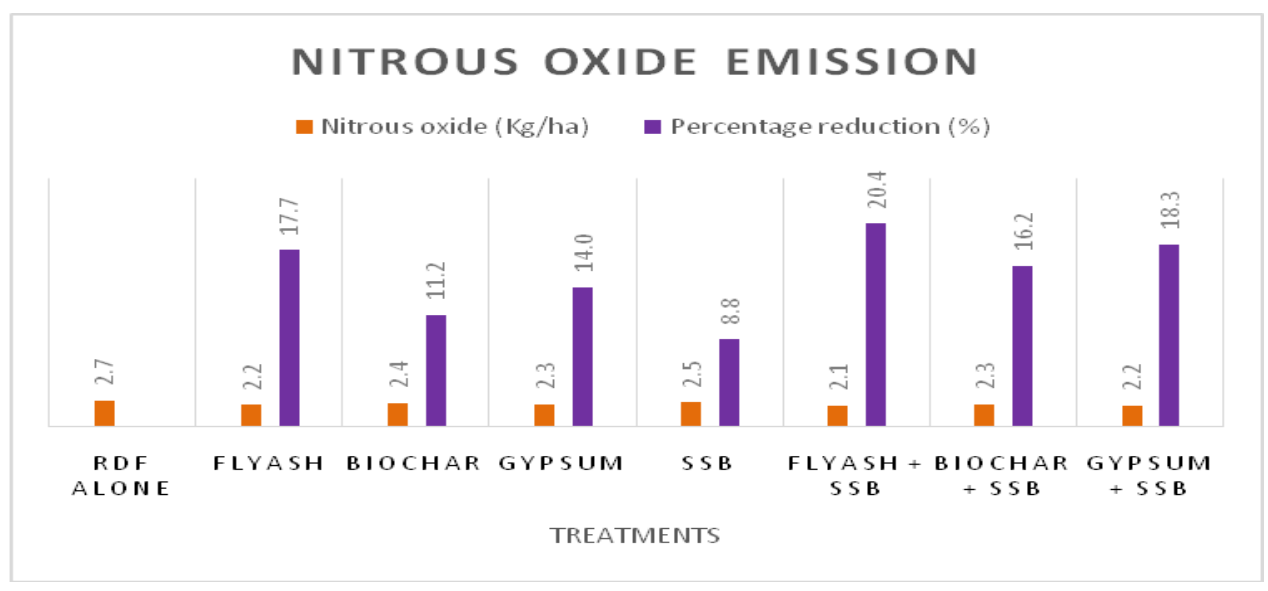


Fig.3 Carbon dioxide emission

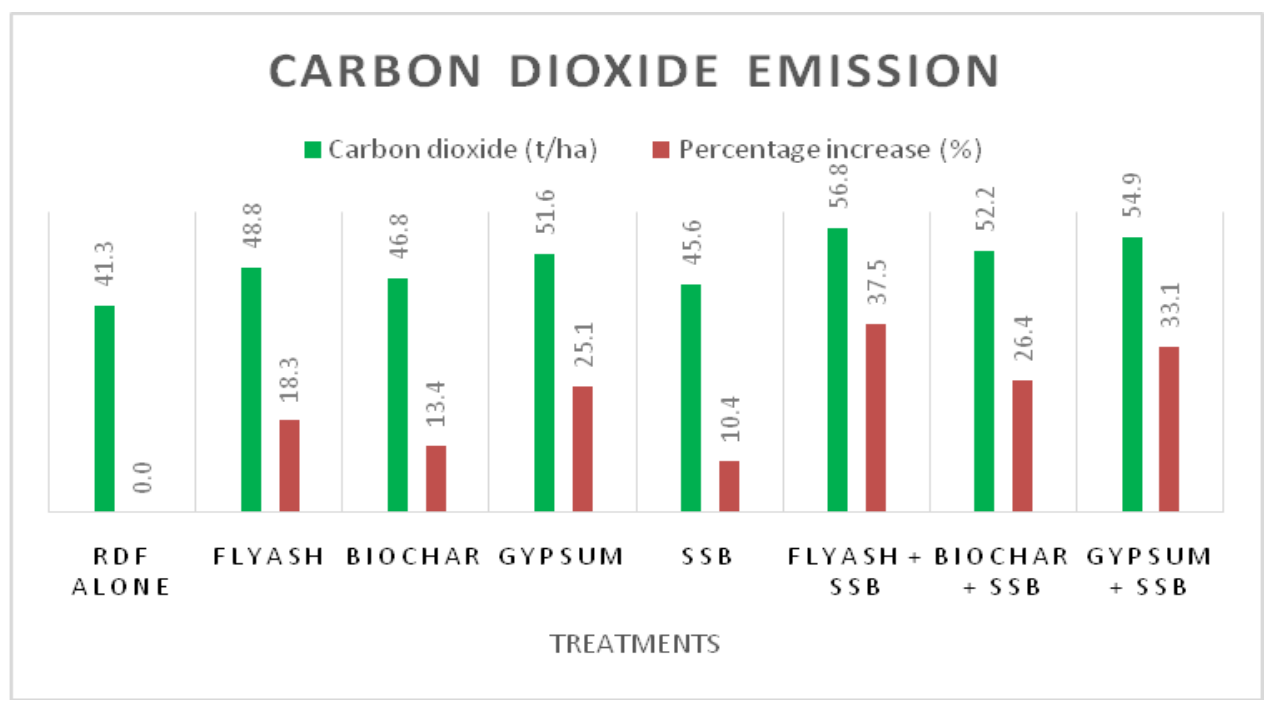

The increased iron and manganese compounds in fly ash and gypsum acts as electron acceptors and thereby, suppress $\mathrm{CH}_{4}$ emission during rice cultivation (Ali et al., 2009). The same level of results could be observed in this research also.

Nitrous oxide from rice field is mainly due to excess application of $\mathrm{N}$ fertilizer and faulty method and times of application of $\mathrm{N}$ in addition to drying of rice fields frequently during cropping season (Nelson et al., 2012). There are investigations that aim on reducing the GHG emission by handling standard agronomic practices and soil amendment (Yadav et al., 2013). The study has also met out the same purpose of reducing nitrous oxide emission. Use of fly-ash as soil ameliorant in place of lime could lead to reduction in $\mathrm{CO}_{2}$ equivalent emissions, thus contributing to minimize global warming (Ferreira et al., 2003).

There are some aerobic microbes in rice soil itself that are capable of sinking methane. Such transformation of methane to carbon dioxide by the oxidation process is carried out by methanotropic bacteria (Schutz et al., 1990).
Conrad and Rothfuss (1991) have observed that about 80 per cent of the potential diffusive $\mathrm{CH}_{4}$ flux through the soil-water interface was oxidized in the oxic surface layers. So this could further increase the amount of carbon dioxide than the methane gas which is more potent compared to the former. This could be the possible reason for increased carbon di oxide emissions.

The results from the field study on application of soil amendments over GHGs emissions concluded that emissions could be reduced by the application of fly ash + SSB, flyash, gypsum + SSB, biochar + SSB, biochar and gypsum than the application of recommended dose of fertilizers and SSB. The soil amendments were found to help in reducing the GHGs emissions from rice crop fields.

\section{References}

AliM A, LeeC H, LeeY B, and KimP J. 2009. Silicate fertilization in no-tillage rice farming for mitigation of methane emission and increasing rice productivity. Agril. Ecosyst. Environ, 132: 16-22.

AliM A, Oh J H and Kim P J. 2007. 
Suppression of Methane Emission from Rice Paddy Soils with Fly ash Amendment. Korean J. Environ. Agric., 26(2): 141-148.

Bouman A F.1991. Argonomic aspects of wetland rice cultivation and associated methane emissions. Biochemistry, 15: 65-88.

Cicerone R J and Shetter J D. 1981. Sources of atmospheric methane: Measurements in rice paddies and a discussion. J. Geophys. Res., 86: 7203-7209.

ConradR, and Rothfuss F. 1991. Methane oxidation in the soil surface layer of flooded rice field and the effect of ammonia, Biol Fertil Soils, 12: 28-32.

Denier Van der Gon H A C, Kropff M J, Van Breemen N, Wassmann R, Lantin R S, Aduna E, Corton T M and Laar $\mathrm{H} \mathrm{H}$. 2002. Optimizing grain yields reduces $\mathrm{CH}_{4}$ emissions from rice paddy fields. Proc. Natl. Acad. Sci. USA, 99(19): 12021-12024.

Department of Agriculture, Tamil Nadu. 2014. In: 14th Executive Committee Meeting, National Food Security Mission, Tamil Nadu, India.

FAO Rice Market Monitor. April 2016. 19:1. www.fao.org/economic/RMM.

Ferreira C, Ribeiro A, Ottosen L. 2003. Possible applications for municipal solid waste fly ash. J Hazard Mater, 96(2-3): 201-16.

Forster P, Ramaswamy V, Artaxo P, Berntsen T, Betts R, Fahey D W and Haywood J. Changes in atmospheric constituents and in radiative forcing. In: Solomon S, Qin D, Manning M, Chen Z, Marquis M, Averyt K B, Tignor M, Miller H L (eds) Climate change 2007: the physical science basis. Contribution of working group I to the fourth assessment report of the intergovernmental panel on climate change. Pp. 130-234.
Gerald C, Nelson, Mark, Rosegrant W, Jawoo Koo, Richard Robertson, Timothy Sulser, Tingju Zhu, Claudia Ringler, Siwa Msangi, Amanda Palazzo, Miroslav Batka, Marilia Magalhaes, Rowena Valmonte-Santos, Mandy Ewing, and David Lee. 2009. Climate Change Impact on Agriculture and Costs of Adaptation. Food Policy Report. International Food Policy Research Institute, Pp-7.

IPCC, 2014: Climate Change 2014: Synthesis Report. Contribution of Working Groups I, II and III to the Fifth Assessment Report of the Intergovernmental Panel on Climate Change [Core Writing Team, R.K. Pachauri and L.A. Meyer (eds.)]. IPCC, Geneva, Switzerland, pp-151.

Jain M C, Pathak H and Bhatia A. 1999. Measurement of greenhouse gas emission from soil and developing emission inventories. In: Greenhouse Gas Emission from Soil, 65 - 78.

Jayadeva H M, Prabhakara Setty T K, Gowda R C, Devendra R, Mallikarjun G B and Bandi A G. 2009. Methane emission as influenced by different crop establishment techniques and organic manures. Agric. Sci. Digest. 29(4): 241 $-245$.

Khosa M K, Sidhu B S and Benbi D K. 2010. Effect of organic materials and rice cultivars on methane emission from rice field. J. Environ. Biol., 31: $281-$ 285.

NelsonM C, MorrisonM, Schanbacher F and YuZ. 2012. Shifts in microbial community structure of granular and liquid biomass in response to changes in feed and digester design in anaerobic digesters receiving foodprocessing waste. Bioresource Technology, 107: 135-143.

Oremland RM. 1988. Biogeochemistry of methanogenic bacteria, Biology of 
anaerobic microorganisms, edited by $\mathrm{A}$ J B Zelender (John Wiley Sons, New York). pp 641-706.

Pingali P L, Hossain M and Gerpacio R V. 1997.Asian Rice Bowls - The Returning Crisis? CAB International, Wallingford.

SchutzH, Seiler W and Conrad R. 1990. Influence of soil temperature on methane emission from paddy fields. Biogeochem, 11: 77-95.

Smith P, Martino D, Cai Z, Gwary D, Janzen H, Kumar P, McCarl B, Ogle S, O'Mara F, Rice C, Scholes B, and Sirotenko O. Agriculture. In: B.Metz, O. R Davidson, P. R. Bosch, R. Dave, L.A Meyer. (eds) Climate Change 2007: Mitigation. Contribution of Working Group III to the Fourth
Assessment Report of the Intergovernmental Panel on Climate Change. Cambridge University Press, Cambridge, 2007, 497-540.

Subrahmanyam Desiraju R, Rao P, Reddy M V and Voleti S R. 2008.Climate Change and its Impact on Rice In: Rice Knowledge Management Portal (RKMP), Hyderabad, 1-27.

Wardle D A, Nilsson M, Zackrisson O. 2008. Fire-derived charcoal causes loss of forest humus. Science, 320-629.

Yadav R C, Prakash O M and DeswalJ S. 2013. Biotechnology of Intra-Row Banding of Cynobacteria Leguminous Crops for Raising Yield Plateau of Cereals and Oilseeds. Int. J. Agron. and Plant Prod, U.K. (In Press)

\section{How to cite this article:}

Kowshika, N., N. Maragatham, V. Geethalakshmi, M. Maheswari and Panneerselvam, S. 2019. Soil Amendments as GHGs Curtailers in Rice Fields. Int.J.Curr.Microbiol.App.Sci. 8(12): 374380. doi: https://doi.org/10.20546/ijcmas.2019.812.050 